\title{
Transformation efficiency and formation of transformation products during photochemical degradation of TCE and PCE at micromolar concentrations
}

\author{
Sina Dobaradaran ${ }^{1,2,3}$, Holger Lutze ${ }^{3}$, Amir Hossein Mahvi $i^{4,5}$ and Torsten C Schmidt ${ }^{3 *}$
}

\begin{abstract}
Background: Trichloroethene and tetrachloroethene are the most common pollutants in groundwater and two of the priority pollutants listed by the U.S. Environmental Protection Agency. In previous studies on TCE and PCE photolysis and photochemical degradation, concentration ranges exceeding environmental levels by far with millimolar concentrations of TCE and PCE have been used, and it is not clear if the obtained results can be used to explain the degradation of these contaminants at more realistic environmental concentration levels.

Methods: Experiments with micromolar concentrations of TCE and PCE in aqueous solution using direct photolysis and $\mathrm{UV} / \mathrm{H}_{2} \mathrm{O}_{2}$ have been conducted and product formation as well as transformation efficiency have been investigated. SPME/GC/MS, HPLC/UV and ion chromatography with conductivity detection have been used to determine intermediates of degradation.

Results: The results showed that chloride was a major end product in both TCE and PCE photodegradation. Several intermediates such as formic acid, dichloroacetic acid, dichloroacetaldehyede, chloroform, formaldehyde and glyoxylic acid were formed during both, UV and UV/ $\mathrm{H}_{2} \mathrm{O}_{2}$ treatment of TCE. However chloroacetaldehyde and chloroacetic acid were only detected during direct UV photolysis of TCE and oxalic acid was only formed during the UV/ $\mathrm{H}_{2} \mathrm{O}_{2}$ process. For PCE photodegradation, formic acid, di- and trichloroacetic acids were detected in both UV and UV/ $\mathrm{H}_{2} \mathrm{O}_{2}$ systems, but formaldehyde and glyoxylic acid were only detected during direct UV photolysis.

Conclusions: For water treatment UV/ $\mathrm{H}_{2} \mathrm{O}_{2}$ seems to be favorable over direct UV photolysis because of its higher degradation efficiency and lower risk for the formation of harmful intermediates.
\end{abstract}

Keywords: Byproduct, Degradation, Photochemical, Trichloroethene, Photolysis

\section{Background}

Presence of volatile organic compounds (VOCs) in water is an important concern to all who use groundwater as a source for different purposes. These compounds such as chlorinated aliphatic hydrocarbons (CAHs) can enter the water sources and endanger human health in a direct or indirect manner. TCE and PCE are two of the most frequently detected groundwater contaminants and have been found from different sources in widespread areas [1-3].

\footnotetext{
* Correspondence: torsten.schmidt@uni-due.de

${ }^{3}$ Instrumental Analytical Chemistry, University Duisburg-Essen, Essen 45141, Germany

Full list of author information is available at the end of the article
}

The U.S. Environmental Protection Agency (EPA) has classified TCE and PCE as priority pollutants on the basis of their possible carcinogenicity, widespread contamination and potential formation of vinyl chloride (VC) during anaerobic bioconversion [4-7]. Most conventional treatment processes such as coagulation, sedimentation, precipitative softening, filtration and chlorination are not efficient in removal of TCE and PCE. Other conventional treatment processes such as adsorption on activated carbon and air stripping are effective in removing these compounds from contaminated water but the contaminants are transferred to another phase, and the residuals still need to be treated [8].

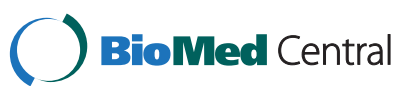


On the other hand, advanced oxidation processes (AOPs) can be considered as efficient complimentary techniques to the conventional treatment processes and may completely destroy toxic organics such as TCE and PCE [9-12]. AOPs such as $\mathrm{UV} / \mathrm{H}_{2} \mathrm{O}_{2}$ produce highly reactive species such as $\mathrm{OH}^{\circ}$ that react rapidly with electron-rich organics and destroy most organic chemical compounds. Under specific conditions, AOPs could lead to complete mineralization of parent contaminants to water, carbon dioxide and mineral acids. The direct photolysis of TCE and PCE has proven to be effective to destroy these compounds in both aqueous and gas phases [13-17].

It was reported that dichloroacetyl chloride was the major primary product in the gas phase photolysis of TCE that in comparison to TCE is more toxic and significantly less degradable. Dichloroacetic acid, chloroform, methylene chloride, phosgene and trichloroacetyl chloride were other reported intermediates [14]. Aqueous phase photolysis of TCE and especially photolysis in combination of chemical has not received as much attention as gas phase photolysis. Chu and Choy [18] measured the photodegradation rate of TCE in surfactant micelles at $254 \mathrm{~nm}$ and reported enhancement of TCE degradation rate due to surfactant addition. During TCE degradation no chlorinated intermediates formation was reported. In another study, the direct UV photolysis of a 58 ppm TCE was studied. In this study $80 \%$ mineralization of TCE solution occurred within $40 \mathrm{~min}$ [19]. Hirvonen et al. [20] measured the removal efficiency of TCE using a low pressure mercury lamp at $254 \mathrm{~nm}$ and reported it as only $20 \%$ of that found for UV photolysis in combination with hydrogen peroxide. In a recent study, Li et al. [21] studied the formation of byproducts and kinetic modeling of TCE during direct photolysis. They reported the chloride ion as major end product and some compounds such as formic acid, di- and monochloroacetic acids, glyoxilic acid, oxalic acid, formaldehyde, mono- and dichloroacetylene and dichloroacetaldehyde as byproducts. In another study, UV photolysis and $\mathrm{UV} / \mathrm{H}_{2} \mathrm{O}_{2}$ degradation of TCE was examined by Hirvonen et al. [22]. They found chloroacetic acids as byproducts by either direct photolysis or $\mathrm{UV} / \mathrm{H}_{2} \mathrm{O}_{2}$. Mertens and Sonntag measured the photolysis of PCE in aqueous solutions at $254 \mathrm{~nm}$, they reported chloride ions, carbon dioxide as end products and trichloroacetic acid, dichloroacetic acid and hypochlorite as the major byproducts [23]. In another study Yamada and Tsuno have reported a higher pseudo-first order rate constant for PCE in comparison to TCE during UV photolysis [24].

During the degradation of TCE and PCE via UV or $\mathrm{UV} / \mathrm{H}_{2} \mathrm{O}_{2}$ some harmful intermediates such as haloacetic acids (HAAs) and chloroform may be formed. These compounds are known as disinfection byproducts (DBPs) in chlorination; therefore, they are strictly monitored during water treatment. For example, the total level of HAAs should not exceed $60 \mu \mathrm{g} / \mathrm{L}$ as the regulatory standard set for drinking water quality by EPA.

Most of the mentioned studies deal with the process efficiency for TCE and PCE removal and degradation byproducts using millimolar concentrations. With regard to concentration ranges of TCE and PCE in previous studies exceeding environmental levels [3] the present study deals with the degradation efficiency of TCE and PCE at five different micromolar concentrations with direct UV photolysis and $\mathrm{UV} / \mathrm{H}_{2} \mathrm{O}_{2}$, identify the possible harmful byproducts and their concentrations at different initial content levels and compare the $\mathrm{UV}$ and $\mathrm{UV} / \mathrm{H}_{2} \mathrm{O}_{2}$ processes in treatment of contaminated water by TCE and PCE.

\section{Methods}

\section{Reagents}

Trichloroethene ( $\geq 99.5 \%)$, tetrachloroethene ( $\geq 99.5 \%)$, formic acid (98\%), chloroacetic acid (99\%), dichloroacetic acid (99.2\%), formaldehyde, trichloroacetic acid ( $\geq 99 \%$ ), oxalic acid ( $\geq 99 \%)$, glyoxylic acid (98\%), chloroacetaldehyde, acetonitrile of HPLC grade ( $\geq 99.9 \%)$, perchloric acid (70\%) all prepared from Sigma Aldrich, sulphuric acid (VWR, 95\%) and chloroform (Aldrich, 99.8\%) were used. All solutions were prepared using ultrapure water (resistivity $18.2 \mathrm{M} \Omega \mathrm{cm}$ ).

\section{Apparatus and analytical methods}

All UV and UV/ $\mathrm{H}_{2} \mathrm{O}_{2}$ experiments were conducted using a Merry-go-round reactor (manufactured by H. \& Th. Schneider Glasapparatebau, Germany).

The photon flow entering the reactor from the $15 \mathrm{~W}$ low pressure mercury lamp was $60.1 \mu$ einstein $\mathrm{m}^{-2} \mathrm{~s}^{-1}$ at $254 \mathrm{~nm}$, as determined by atrazine actinometry.

In each UV experiment, $60 \mathrm{~mL}$ of TCE and PCE solution at different concentrations (3.8, 7.6, 76.1, 190.3 and $380.5 \mu \mathrm{M})$, were transferred into separate cylindrical quartz vessels, placed inside the reactor and illuminated with monochromatic UV lamps.

In $\mathrm{UV} / \mathrm{H}_{2} \mathrm{O}_{2}$ experiments, a molar ratio of $\mathrm{H}_{2} \mathrm{O}_{2}$ to TCE and PCE equal to 200 was added to TCE and PCE solutions of different concentrations (as above).

The temperature inside the reactor was maintained at $25^{\circ} \mathrm{C}$ by a water bath and circulator (HAAKE F6).

Samples were taken from the quartz vessel at different predetermined reaction times $(1,3,5,10,20,40,60$ and $70 \mathrm{~min})$.

The dissolved oxygen level and $\mathrm{pH}$ were immediately determined after each run by HACH HQ40d DO meter and Metrohm $827 \mathrm{pH}$ meter, respectively.

GC/MS (Shimadzu-QP2010) with a splitless injector and a $30 \mathrm{~m}^{*} 0.25 \mathrm{~mm}$ id* $0.25 \mu \mathrm{m}$ fused silica capillary 
column (RxiTM-5 ms) using headspace solid-phase microextraction (SPME) was used to determine TCE, PCE, chloroform, chloroacetaldehyde and dichloroacetaldehyde. Helium 5.0 was used as carrier gas, one ramp temperature program was employed with an initial temperature of $40^{\circ} \mathrm{C}$ for $2 \mathrm{~min}$, followed by a ramp of $5^{\circ} \mathrm{C} /$ min to $120^{\circ} \mathrm{C}$ and held for $2 \mathrm{~min}$. Ion source, injection and interface temperatures were 200,280 and $250^{\circ} \mathrm{C}$, respectively.

The concentrations of chloride ion, oxalic acid, formic acid, di-, tri- and monochloroacetic acids were determined by ion chromatography (Metrohm 883 basic IC equipped with ion separation and conductivity detector, a Metrohm 863 compact autosampler, Metrosep A supp 4 column. An aqueous solution of carbonate/bicarbonate $1.7 \mathrm{mM} \mathrm{NaHCO}_{3}$ and $1.8 \mathrm{mM} \mathrm{Na}_{2} \mathrm{CO}_{3}$ has been used as eluent in isocratic mode).

Formaldehyde and glyoxylic acid were measured as dinitrophenylhydrazones using a Agilent 1100 HPLC/ UV system (with C18 Reversed Phase column manufactured by Macherey- Nagel).

\section{Results and discussion}

Degradation kinetics of aqueous TCE and PCE solutions

Aqueous solutions with initial concentrations of TCE and PCE of 3.8, 7.6, 76.1, 190.3 and $380.5 \mu \mathrm{M}$ were illuminated in direct photolysis and also in $\mathrm{UV} / \mathrm{H}_{2} \mathrm{O}_{2}$ processes.

Linear regression of the logarithm of TCE concentrations versus reaction time allowed calculating the firstorder reaction rate constants.

As presented in Table 1, an increasing degradation rate of TCE and PCE with decreasing initial concentration is observed. The first order degradation rate increases by a factor of 4 and 5 for TCE and 3.5 and 6.2 for PCE in UV and $\mathrm{UV} / \mathrm{H}_{2} \mathrm{O}_{2}$ processes, respectively, when the concentration at $\mathrm{t}=0$ drops from 380.5 to $3.8 \mu \mathrm{M}$.
This is due to lower photon/contaminants ratio when the TCE and PCE concentrations are increased in the solution. When TCE and PCE start to be degraded and the byproducts simultaneously begin to be generated, the presence of byproducts in the solutions will retard the overall degradation of contaminants and also their byproducts.

A rapid initial degradation in the beginning of the processes, followed by a slower degradation rate, was found during the photodegradation of contaminants (in both UV and $\mathrm{UV} / \mathrm{H}_{2} \mathrm{O}_{2}$ processes). Similar observations were also reported by other studies at diluted concentrations $[25,26]$.

\section{Change of $\mathrm{pH}$ during the processes}

The change of $\mathrm{pH}$ during irradiation in solutions at different initial TCE and PCE concentrations (3.8, 7.6, 76.1, 190.3 and $380.5 \mu \mathrm{M}$ ) was examined (in both UV and $\mathrm{UV} / \mathrm{H}_{2} \mathrm{O}_{2}$ systems) with a similar initial $\mathrm{pH}$ of around 5.5. The variation of $\mathrm{pH}$ at highest initial concentrations of TCE and PCE is shown in Figure 1.

At low concentrations of contaminants (3.8 and $7.6 \mu \mathrm{M})$ variation of $\mathrm{pH}$ in solution was insignificant due to the small amount of protons produced in both systems ( $\mathrm{UV}$ and $\mathrm{UV} / \mathrm{H}_{2} \mathrm{O}_{2}$ ). At higher initial concentrations though, as shown in Figure $1(\mathrm{a}-\mathrm{b})$, the initial $\mathrm{pH}$ of solutions drops sharply (especially in the $\mathrm{UV} / \mathrm{H}_{2} \mathrm{O}_{2}$ system) after onset of irradiation $(t<3 \mathrm{~min})$. The decrease in $\mathrm{pH}$ indicates that protons are generated as one of the major end products of the TCE and PCE photodegradation. The high amount of protons generated during UV irradiation retards degradation of PCE and TCE, so the overall reaction rates were lower at low levels of $\mathrm{pH}$.

\section{Transformation products formation}

Transformation products formed during irradiation of TCE and PCE at five initial different concentration levels

Table 1 First order degradation rate constants of TCE and PCE at different concentrations, time of process and $\%$ removal in UV and $\mathrm{UV} / \mathrm{H}_{2} \mathrm{O}_{2}$ systems

\begin{tabular}{|c|c|c|c|c|c|c|c|}
\hline \multirow{2}{*}{$\begin{array}{c}\text { Initial } \\
\text { concentration }(\mu \mathrm{M})\end{array}$} & \multirow{2}{*}{$\begin{array}{l}\text { TCE \& } \\
\text { PCE }\end{array}$} & \multicolumn{3}{|c|}{ UV process } & \multicolumn{3}{|c|}{$\mathrm{UV} / \mathrm{H}_{2} \mathrm{O}_{2}$ process } \\
\hline & & $k_{1}\left(\min ^{-1}\right)$ & $\begin{array}{c}\text { Time of } \\
\text { process (min) }\end{array}$ & Removal (\%) & $\mathrm{k}_{1}\left(\min ^{-1}\right)$ & $\begin{array}{c}\text { Time of } \\
\text { process (min) }\end{array}$ & Removal (\%) \\
\hline \multirow[t]{2}{*}{3.8} & TCE & 0.0847 & 40 & 100 & 0.1766 & 10 & 100 \\
\hline & PCE & 0.0888 & 40 & 100 & 0.251 & 10 & 100 \\
\hline \multirow[t]{2}{*}{7.6} & TCE & 0.0519 & 60 & 100 & 0.1613 & 20 & 100 \\
\hline & PCE & 0.0573 & 60 & 100 & 0.1915 & 20 & 100 \\
\hline \multirow[t]{2}{*}{76.1} & TCE & 0.0269 & 70 & 91 & 0.0816 & 40 & 100 \\
\hline & PCE & 0.0392 & 70 & 97.54 & 0.0966 & 40 & 100 \\
\hline \multirow[t]{2}{*}{190.3} & TCE & 0.0235 & 70 & 88.36 & 0.0467 & 60 & 100 \\
\hline & PCE & 0.0358 & 70 & 95.92 & 0.0549 & 60 & 100 \\
\hline \multirow[t]{2}{*}{380.5} & TCE & 0.0209 & 70 & 82.3 & 0.0348 & 70 & 95.8 \\
\hline & PCE & 0.0254 & 70 & 88.66 & 0.0405 & 70 & 97.7 \\
\hline
\end{tabular}



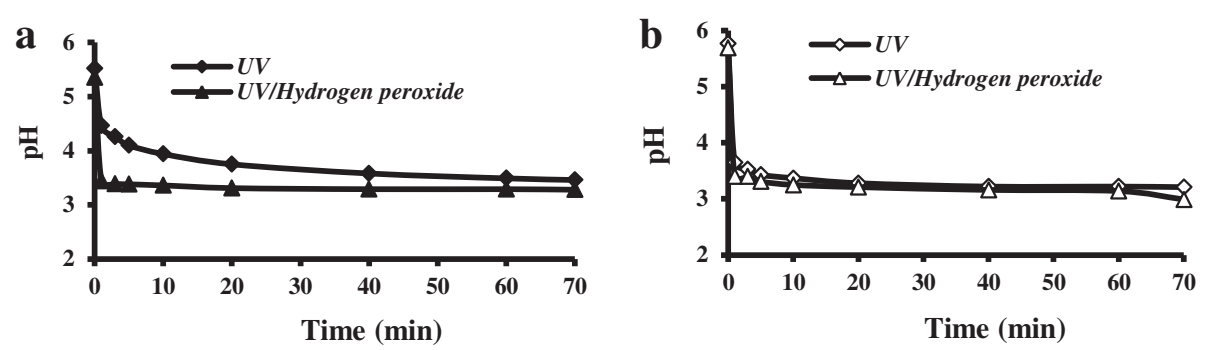

Figure $1 \mathrm{pH}$ change during TCE (a) and PCE (b) degradation in UV and $\mathrm{UV} / \mathrm{H}_{2} \mathrm{O}_{2}$ processes at initial concentration of $380.5 \mu \mathrm{M}$, molar ratio of $\mathrm{H}_{2} \mathrm{O}_{2}$ to TCE and PCE equal to 200 .

(3.8, 7.6, 76.1, 190.3 and $380.5 \mu \mathrm{M})$ were examined. Intermediate formation will be discussed for the highest concentration $(380.5 \mu \mathrm{M})$ with $\mathrm{UV}$ and $\mathrm{UV} / \mathrm{H}_{2} \mathrm{O}_{2}$ processes.

For both TCE and PCE, chloride is a major end product. Several intermediates such as formic acid, dichloroacetic acid, dichloroacetaldyde, formaldehyde and glyoxylic acid were formed during both $\mathrm{UV}$ and $\mathrm{UV} / \mathrm{H}_{2} \mathrm{O}_{2}$ treatment of TCE. However chloroacetaldyde, chloroacetic acid and chloroform were detected only during direct UV photolysis and oxalic acid was formed only during the $\mathrm{UV} / \mathrm{H}_{2} \mathrm{O}_{2}$ system (Figures 2, 3, 4, 5 and Table 2). However, it is interesting to note that during $\mathrm{UV} / \mathrm{H}_{2} \mathrm{O}_{2}$ process at lowest initial concentration of TCE $(3.8 \mu \mathrm{M})$ low concentration of chloroform was detected (Table 3), but after $40 \mathrm{~min}$, chloroform was removed completely. Formic acid, dichloroacetic acid and trichloroacetic acid were detected during both UV and UV/ $\mathrm{H}_{2} \mathrm{O}_{2}$ treatment of PCE but formaldehyde and glyoxylic acid were only formed during UV photolysis (Figures 2, 3, 4, 5). Beside chloride as the major end product, formic acid and dichloroacetic acid were the main intermediates (with regard to their concentration) during both $\mathrm{UV}$ and $\mathrm{UV} / \mathrm{H}_{2} \mathrm{O}_{2}$ treatment of TCE and for PCE di- and trichloroacetic acid were the main intermediates in both systems. However, the kinetics of formation and further transformation of those compounds during the processes were different (Figures 2, 3, 4, 5).

For TCE, the dynamics of the UV process suggests that chloride, formic acid, chloroacetic acid, dichloroacetic acid and glyoxylic acid were continuously generated.

Among these compounds, chloride, formic acid and dichloroacetic acid are formed at early irradiation stage in the UV system (Figures 2 and 4), but in the $\mathrm{UV} / \mathrm{H}_{2} \mathrm{O}_{2}$ system just chloride was continuously generated (Figure 3 ). For PCE, the dynamics of the UV process showed that chloride, formaldehyde, di- and trichloroacetic acid were formed at early photolysis stage whereas formic acid and glyoxylic acid were formed only after 20 and $40 \mathrm{~min}$, respectively (Figures 2 and 4). In contrast, in the $\mathrm{UV} / \mathrm{H}_{2} \mathrm{O}_{2}$ system formic acid, di- and trichloroacetic acid were detected at early stages. After 60 and $70 \mathrm{~min} \mathrm{di}$ and trichloroacetic acid were removed completely (Figure 5). The chlorine balance at the end of the experiment (70 min) indicates that for TCE approximately $12 \%$ and $10.7 \%$ less chloride than the initial level $(\sim 1141.5 \mu \mathrm{M}, \mathrm{t}=$ $0 \mathrm{~min}$ ) in $\mathrm{UV}$ and $\mathrm{UV} / \mathrm{H}_{2} \mathrm{O}_{2}$ systems respectively (with consider $82.3 \%$ and $95.8 \%$ TCE removal in UV and UV/ $\mathrm{H}_{2} \mathrm{O}_{2}$ system respectively). For PCE, these values were 10.5 and $8.2 \%(\sim 1522 \mu \mathrm{M}, \mathrm{t}=0 \mathrm{~min})$ in $\mathrm{UV}$ and $\mathrm{UV} /$ $\mathrm{H}_{2} \mathrm{O}_{2}$ systems respectively (with consider $88.6 \%$ and

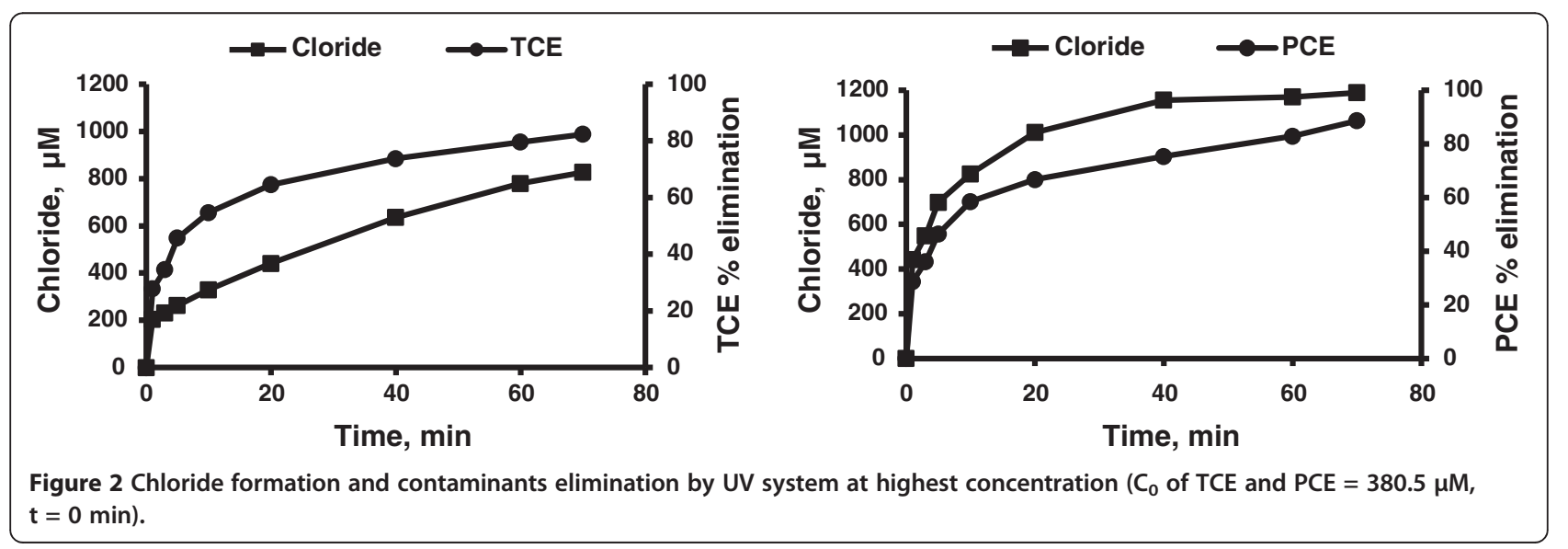



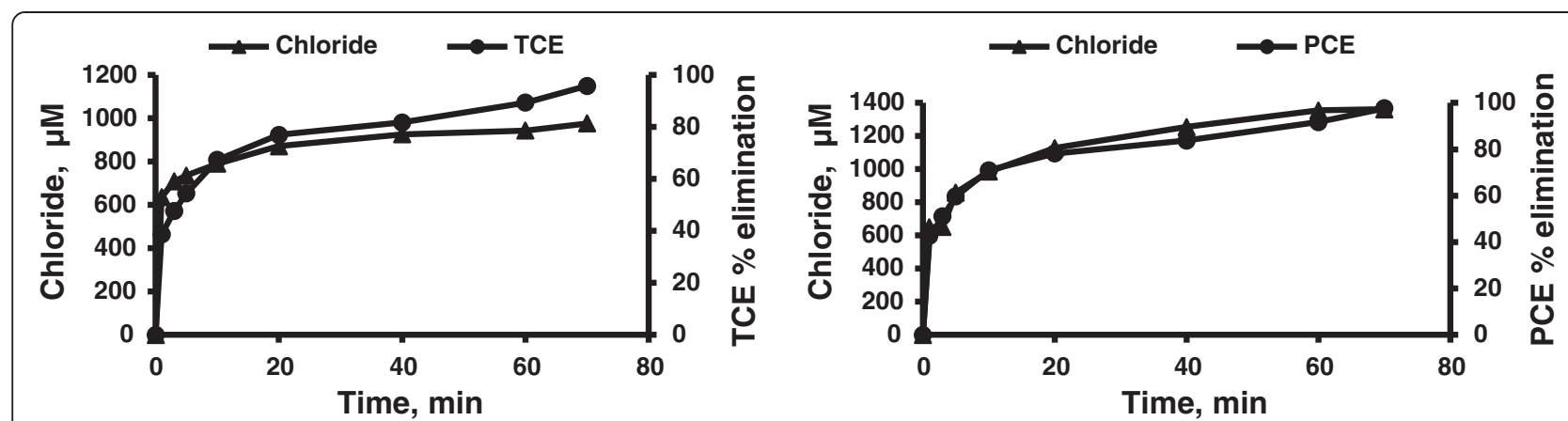

Figure 3 Chloride formation and contaminants elimination by $\mathrm{UV} / \mathrm{H}_{2} \mathrm{O}_{2}$ system at highest concentration $\left(\mathrm{C}_{0}\right.$ of TCE and PCE $=380.5 \mu \mathrm{M}$, $\mathrm{t}=0 \mathrm{~min}$, molar ratio of $\mathrm{H}_{2} \mathrm{O}_{2}$ to TCE and PCE equal to 200).

97.7\% PCE removal in UV and $\mathrm{UV} / \mathrm{H}_{2} \mathrm{O}_{2}$ system respectively). This may be due to molecular chlorine, which should be among the inorganic species generated during the degradation and mineralization of chlorinated organics in $\mathrm{UV}$ and $\mathrm{UV} / \mathrm{H}_{2} \mathrm{O}_{2}$ process. Hypochlorous acid ( $\mathrm{HOCl}$ ) was formed during the early stage of irradiation in both UV and $\mathrm{UV} / \mathrm{H}_{2} \mathrm{O}_{2}$ systems. This compound will be formed from low levels of molecular chlorine dissolved in water [21].
$\mathrm{HOCl}$ is not a strong absorber of $\mathrm{UV}$ and the photolysis of this compound generates chlorine atoms and hydroxyl radicals, which may be further involved in degradation and oxidative reactions.

During light absorption, TCE and PCE degrade in aqueous solution by several major processes: (a) photostimulated hydrolysis, (b) homolytic cleavage of $\mathrm{C}-\mathrm{Cl}$ bond, (c) loss of $\mathrm{HCl}$, (d) loss of molecular chlorine.

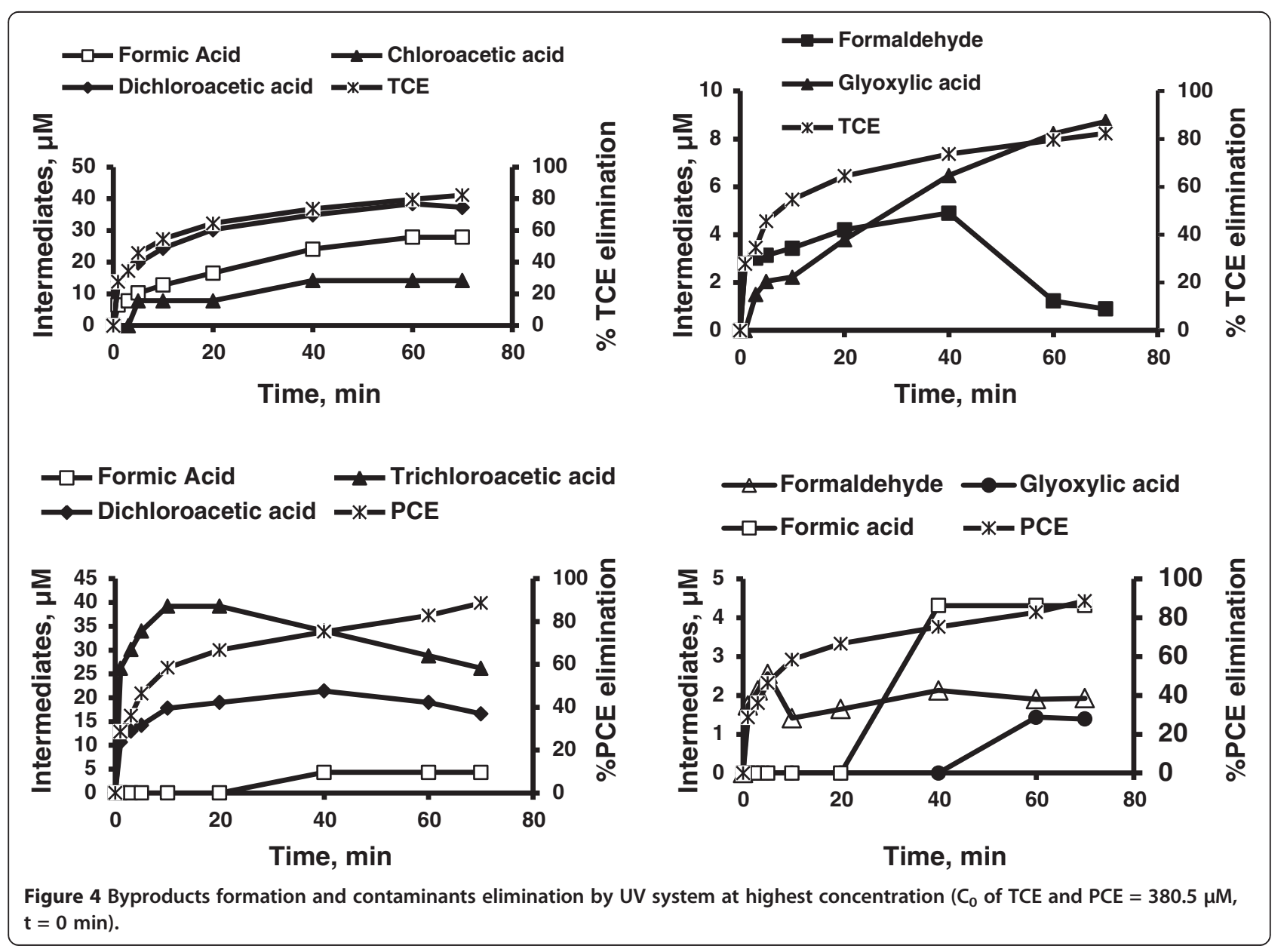




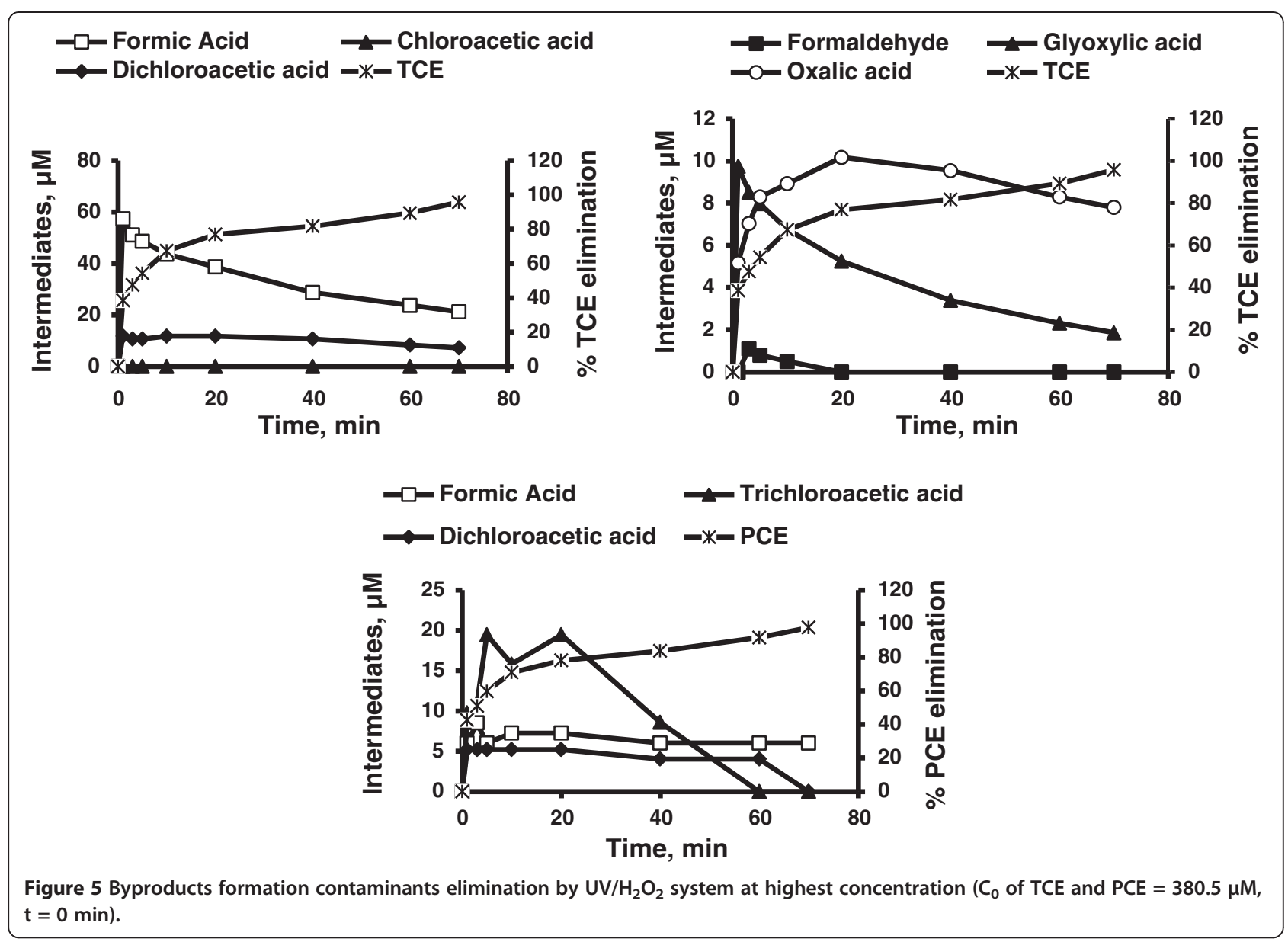

When hydrogen peroxide is used in combination with UV light, photolysis of $\mathrm{H}_{2} \mathrm{O}_{2}$ leads to formation of more hydroxyl radicals in the system [27] so the destruction of contaminants and their byproducts will be faster and more efficient.
Comparison of detected harmful transformation products levels during $\mathrm{UV}$ and $\mathrm{UV} / \mathrm{H}_{2} \mathrm{O}_{2}$ with EPA standards

Chloroacetic acid, dichloroacetic acid and chloroform were detected during treatment of aqueous TCE solutions by direct photolysis and dichloroacetic acid was

Table 2 Transformation product formation (chloroacetaldehyde and dichloroacetaldehyde) and TCE elimination by UV and $\mathrm{UV} / \mathrm{H}_{2} \mathrm{O}_{2}$ systems at highest concentration $\left(\mathrm{C}_{0}\right.$ of TCE $=380.5 \mu \mathrm{M}, \mathrm{t}=\mathbf{0} \mathrm{min}$, molar ratio of $\mathrm{H}_{2} \mathrm{O}_{2}$ to $\mathrm{TCE}$ equal to 200)

\begin{tabular}{|c|c|c|c|c|c|c|}
\hline \multirow{2}{*}{$\begin{array}{l}\text { Run time } \\
\text { (min) }\end{array}$} & \multicolumn{3}{|c|}{ UV process } & \multicolumn{3}{|c|}{$\mathrm{UV} / \mathrm{H}_{2} \mathrm{O}_{2}$ process } \\
\hline & Chloroacetaldehyde $(\mathrm{A})^{*}$ & Dichloroacetaldehyede (A) & $\begin{array}{c}\% \text { TCE } \\
\text { elimination }\end{array}$ & Chloroacetaldehyde (A) & Dichloroacetaldehyede (A) & $\begin{array}{c}\% \text { TCE } \\
\text { elimination }\end{array}$ \\
\hline 1 & 0 & 70346704 & 27.76 & 0 & 838788 & 38.6 \\
\hline 3 & 4573490 & 96891592 & 34.6 & 0 & 619849 & 47.58 \\
\hline 5 & 3012691 & 135801181 & 45.72 & 0 & 323674 & 54.44 \\
\hline 10 & 971776 & 164873121 & 54.7 & 0 & 218737 & 67.36 \\
\hline 20 & 2305688 & 247528613 & 64.52 & 0 & 0 & 76.94 \\
\hline 40 & 537962 & 187861453 & 73.7 & 0 & 0 & 81.76 \\
\hline 60 & 429982 & 148046610 & 79.58 & 0 & 0 & 89.36 \\
\hline 70 & 0 & 243483108 & 82.3 & 0 & 0 & 95.8 \\
\hline
\end{tabular}

*Measured area via GC/MS. 
Table 3 Final concentrations of harmful transformation products during UV/ $\mathrm{H}_{2} \mathrm{O}_{2}$ processes of TCE \& PCE and compare with EPA guidelines

\begin{tabular}{|c|c|c|c|c|c|c|c|c|c|c|c|c|}
\hline \multirow{3}{*}{$\begin{array}{l}\text { Initial concentration of } \\
\text { TCE \& PCE }\end{array}$} & \multirow[t]{3}{*}{ Contaminants } & \multicolumn{5}{|l|}{ UV process } & \multicolumn{6}{|c|}{ EPA guideline } \\
\hline & & \multirow[t]{2}{*}{$\begin{array}{l}\text { Reaction } \\
\text { time (min) }\end{array}$} & \multicolumn{4}{|c|}{$\begin{array}{l}\text { Concentration of contaminants and their transformation } \\
\text { products after reaction time }(\mu \mathrm{g} / \mathrm{L})\end{array}$} & \multicolumn{2}{|c|}{ TCE \& PCE $(\mu \mathrm{g} / \mathrm{L})$} & \multicolumn{2}{|c|}{ HAAs $(\mu g / L)$} & \multicolumn{2}{|c|}{ THMs $(\mu \mathrm{g} / \mathrm{L})$} \\
\hline & & & TCE/PCE & $\begin{array}{l}\text { Dichloroacetic } \\
\text { acid }\end{array}$ & $\begin{array}{l}\text { Haloacetic } \\
\text { acid }\end{array}$ & $\begin{array}{l}\text { Chloroform } \\
\text { (THMs) }\end{array}$ & $\mathrm{MCL}^{\mathrm{a}}$ & $M^{\prime} C^{b}$ & $\mathrm{MCL}$ & MCLG & $\mathrm{MCL}$ & MCLG \\
\hline \multirow[t]{2}{*}{$3.8 \mu \mathrm{M}(0.5$ mg/L) } & TCE & 10 & BLD & BLD & $\mathrm{BLD}^{* *}$ & $0.6^{*}$ & 5 & 0 & 60 & $\mathrm{n} / \mathrm{a}$ & 80 & $\mathrm{n} / \mathrm{a}$ \\
\hline & PCE & 10 & BLD & BLD & BLD & BLD & \multirow{3}{*}{\multicolumn{6}{|c|}{$\begin{array}{l}\text { Although there is no collective MCLG for this contaminant group, there are } \\
\text { individual MCLGs for some of the individual contaminants: Trihalomethanes: } \\
\text { bromodichloromethane (zero); bromoform (zero); dibromochloromethane } \\
(0.06 \mathrm{mg} / \mathrm{L}) \text { : chloroform }(0.07 \mathrm{mg} / \mathrm{L}) \text {. }\end{array}$}} \\
\hline \multirow[t]{2}{*}{$7.6 \mu \mathrm{M}(1 \mathrm{mg} / \mathrm{L})$} & TCE & 20 & BLD & BLD & BLD & BLD & & & & & & \\
\hline & PCE & 20 & BLD & BLD & BLD & BLD & & & & & & \\
\hline \multirow[t]{2}{*}{76.1 ㅆM (10 mg/L) } & TCE & 40 & BLD & BLD & BLD & BLD & & & & & & \\
\hline & PCE & 40 & BLD & BLD & BLD & BLD & & & & & & \\
\hline \multirow[t]{2}{*}{$190.3 \mu \mathrm{m}(25 \mathrm{mg} / \mathrm{L})$} & TCE & 60 & BLD & BLD & BLD & BLD & \multirow{2}{*}{\multicolumn{6}{|c|}{$\begin{array}{l}\text { Haloacetic acids: dichloroacetic acid (zero); trichloroacetic acid }(0.02 \mathrm{mg} / \mathrm{L}) \text {; } \\
\text { chloroacetic acid }(0.07 \mathrm{mg} / \mathrm{L}) \text {. Bromoacetic acid and dibromoacetic acid are } \\
\text { regulated with this group but have no MCLGs. }\end{array}$}} \\
\hline & PCE & 60 & BLD & BLD & BLD & BLD & & & & & & \\
\hline \multirow[t]{2}{*}{$380.5 \mu \mathrm{M}(50$ mg/L) } & TCE & 70 & 2100 & 933.6 & 933.6 & BLD & & & & & & \\
\hline & PCE & 70 & 1150 & BLD & BLD & BLD & & & & & & \\
\hline
\end{tabular}

*after 40 min was removed completely (BLD).

*"BLD: Below detection limit.

aMaximum Concentration Levels.

${ }^{\mathrm{b}}$ Maximum Concentration Levels Goal. 
Table 4 Final concentrations of harmful transformation products during UV processes of TCE \& PCE and compare with EPA guidelines

\begin{tabular}{|c|c|c|c|c|c|c|c|c|c|c|c|c|c|c|}
\hline \multirow{3}{*}{$\begin{array}{l}\text { Initial concentration of } \\
\text { TCE \& PCE }\end{array}$} & \multirow[t]{3}{*}{ Contaminants } & \multicolumn{7}{|l|}{ UV process } & \multicolumn{6}{|c|}{ EPA guideline } \\
\hline & & \multirow[t]{2}{*}{$\begin{array}{l}\text { Reaction } \\
\text { time (min) }\end{array}$} & \multicolumn{6}{|c|}{$\begin{array}{l}\text { Concentration of contaminants and their transformation products after reaction } \\
\text { time }(\mu \mathrm{g} / \mathrm{L})\end{array}$} & \multicolumn{2}{|c|}{$\begin{array}{l}\text { TCE \& PCE } \\
(\mu \mathrm{g} / \mathrm{L})\end{array}$} & \multicolumn{2}{|c|}{ HAAs $(\mu \mathrm{g} / \mathrm{L})$} & \multicolumn{2}{|c|}{ THMs $(\mu \mathrm{g} / \mathrm{L})$} \\
\hline & & & $\begin{array}{l}\text { TCE/ } \\
\text { PCE }\end{array}$ & $\begin{array}{l}\text { Chloroacetic } \\
\text { acid }\end{array}$ & $\begin{array}{l}\text { Dichloroacetic } \\
\text { acid }\end{array}$ & $\begin{array}{l}\text { Trichloroacetic } \\
\text { acid }\end{array}$ & $\begin{array}{l}\text { Haloacetic } \\
\text { acid }\end{array}$ & $\begin{array}{l}\text { Chloroform } \\
\text { (THMs) }\end{array}$ & $\overline{\mathrm{MCL}^{\mathrm{a}}}$ & $\mathrm{MCLG}^{\mathrm{b}}$ & $\overline{\mathrm{MCL}}$ & MCLG & $\overline{\mathrm{MCL}}$ & MCLG \\
\hline \multirow[t]{2}{*}{$3.8 \mu \mathrm{M}(0.5 \mathrm{mg} / \mathrm{L})$} & TCE & 40 & $\mathrm{BLD}^{*}$ & BLD & BLD & BLD & BLD & BLD & 5 & 0 & 60 & $\mathrm{n} / \mathrm{a}$ & 80 & $\mathrm{n} / \mathrm{a}$ \\
\hline & PCE & 40 & BLD & BLD & BLD & BLD & BLD & BLD & \multirow{5}{*}{\multicolumn{6}{|c|}{$\begin{array}{l}\text { Although there is no collective MCLG for this } \\
\text { contaminant group, there are individual MCLGs for } \\
\text { some of the individual contaminants: Trihalomethanes } \\
\text { bromodichloromethane (zero); bromoform (zero); } \\
\text { dibromochloromethane (0.06 } \mathrm{mg} / \mathrm{L}) \text { : chloroform } \\
(0.07 \mathrm{mg} / \mathrm{L}) \text {. }\end{array}$}} \\
\hline \multirow[t]{2}{*}{$7.6 \mu \mathrm{M}(1 \mathrm{mg} / \mathrm{L})$} & TCE & 60 & BLD & BLD & BLD & BLD & BLD & BLD & & & & & & \\
\hline & PCE & 60 & BLD & BLD & BLD & BLD & BLD & BLD & & & & & & \\
\hline \multirow[t]{2}{*}{$76.1 \mu \mathrm{M}(10 \mathrm{mg} / \mathrm{L})$} & TCE & 70 & 900 & BLD & 387.7 & BLD & 387.7 & BLD & & & & & & \\
\hline & PCE & 70 & 246 & BLD & 233.6 & BLD & 233.6 & BLD & & & & & & \\
\hline \multirow[t]{2}{*}{$190.3 \mu \mathrm{m}(25$ mg/L) } & TCE & 70 & 2910 & 1045 & 1851.8 & BLD & 2896.8 & 2.75 & \multirow{4}{*}{\multicolumn{6}{|c|}{$\begin{array}{l}\text { Haloacetic acids: dichloroacetic acid (zero); } \\
\text { trichloroacetic acid }(0.02 \mathrm{mg} / \mathrm{L}) ; \text { chloroacetic acid } \\
(0.07 \mathrm{mg} / \mathrm{L}) \text {. Bromoacetic acid and dibromoacetic acid } \\
\text { are regulated with this group but have no MCLGs. }\end{array}$}} \\
\hline & PCE & 70 & 1020 & BLD & 823.9 & 1433.7 & 2257.6 & BLD & & & & & & \\
\hline \multirow[t]{2}{*}{$380.5 \mu \mathrm{M}(50 \mathrm{mg} / \mathrm{L})$} & TCE & 70 & 8850 & 1343 & 4807 & BLD & 6150 & 3.85 & & & & & & \\
\hline & PCE & 70 & 5670 & BLD & 2144.4 & 4283 & 6427.4 & BLD & & & & & & \\
\hline
\end{tabular}

"BLD: Below detection limit.

a Maximum Concentration Levels.

${ }^{\mathrm{b}}$ Maximum Concentration Levels Goal. 
formed in $\mathrm{UV} / \mathrm{H}_{2} \mathrm{O}_{2}$ process (also chloroform at the lowest initial concentration of TCE) (Table 4 and Table 3). For PCE, di- and trichloroacetic acids were detected in both $\mathrm{UV}$ and $\mathrm{UV} / \mathrm{H}_{2} \mathrm{O}_{2}$ systems.

As shown in Table 4 and Table 3, dichloroacetic acid reaches the highest concentration of all transformation products in both $\mathrm{UV}$ and $\mathrm{UV} / \mathrm{H}_{2} \mathrm{O}_{2}$ processes during degradation of TCE.

Considering the concentrations of harmful transformation products in Table 4 and Table 3 it seems that the UV process is a promising treatment method only at low concentrations of TCE and PCE $(0.5$ and $1 \mathrm{mg} / \mathrm{L})$.

In contrast, $\mathrm{UV} / \mathrm{H}_{2} \mathrm{O}_{2}$ was a promising treatment method in removing contaminants also at higher concentrations.

Although at the highest initial concentration of TCE, high concentration of dichloroacetic acid was produced that exceeded the MCL levels of EPA standards. For PCE, although during $\mathrm{UV} / \mathrm{H}_{2} \mathrm{O}_{2}$ process di- and trichloroacetic acids were formed but in the final reaction times, these compounds were not detected (Table 4 and Table 3 ).

\section{Conclusion}

In summary, the initial degradation of TCE and PCE with $\mathrm{UV}$ and $\mathrm{UV} / \mathrm{H}_{2} \mathrm{O}_{2}$ was more rapid in the beginning of the processes. It is confirmed in this study that initial concentration of TCE and PCE has an important role on the degradation rate constants and also generation of transformation products.

The use of direct UV irradiation when taking into account formation of harmful transformation products was successful only at low initial concentrations of TCE and PCE $(3.8$ and $7.6 \mu \mathrm{M})$.

TCE removal via $\mathrm{UV} / \mathrm{H}_{2} \mathrm{O}_{2}$ was suitable at higher initial levels of TCE $(3.8,7.6,76.1$ and $190.3 \mu \mathrm{M})$ and for PCE this process $\left(\mathrm{UV} / \mathrm{H}_{2} \mathrm{O}_{2}\right)$ was suitable at all concentration levels in this study.

Finally, from these data it is concluded that HAAs formation from the photodegradation of TCE and PCE in raw water will be no problem in the UV disinfection of drinking water (considering their rather low environmental levels). But at higher concentrations ( $>1 \mathrm{mg} / \mathrm{L}$ ) for TCE and PCE degradation $\mathrm{UV} / \mathrm{H}_{2} \mathrm{O}_{2}$ seems to be favorable over direct UV photolysis due to its higher degradation efficiency and lower risk for the formation of harmful intermediates.

\section{Competing interests}

The authors declare that they have no competing interests.

\section{Authors' contributions}

SD has design and performed all experiments, analyzed data as well as wrote the manuscript. HL has quided the laboratory analysis, interpretation techniques and experiments structure. AHM has guided in the experiments design and manuscript preparation. TCS has designed the final version of experiments, final polishing and editing of manuscript as well as he was the supervisor of this study in all steps. All authors read and approved the final manuscript.

\section{Acknowledgements}

The authors are grateful to all department staffs of the Instrumental Analytical Chemistry group, University Duisburg- Essen.

\section{Author details}

${ }^{1}$ The Persian Gulf Marine Biotechnology Research Center, Bushehr University of Medical Sciences, Bushehr, Iran. ${ }^{2}$ Department of Environmental Health Engineering, Faculty of Health, Bushehr University of Medical Sciences, Bushehr, Iran. ${ }^{3}$ Instrumental Analytical Chemistry, University Duisburg-Essen, Essen 45141, Germany. ${ }^{4}$ Department of Environmental Health Engineering, School of Public Health, Tehran University of Medical Sciences, Tehran, Iran.

${ }^{5}$ Center for Solid Waste Research, Institute for Environmental Research, Tehran University of Medical Sciences, Tehran, Iran.

Received: 11 April 2013 Accepted: 10 November 2013 Published: 8 January 2014

\section{References}

1. Moran MJ, Zogorski JS, Squillace PJ: Chlorinated solvents in groundwater of the United States. Environ Sci Technol 2007, 41(1):74-81.

2. Fetter CW: Applied hydrogeology. 2nd edition. Columbus: Merrill Publishing Co; 1988.

3. Dobaradaran S, Mahvi AH, Nabizadeh R, Mesdaghinia A, Naddafi K, Yunesian M, Rastkari N, Nazmara S: Hazardous organic compounds in groundwater near Tehran automobile industry. Bull Environ Contam Toxicol 2010, 85(5):530-533.

4. Distefano TD, Gossett JM, Zinder SH: Hydrogen as anelectron donor for dechlorination of tetrachloroethene by an anaerobic mixed culture. Appl Environ Microbiol 1992, 58:3622-3629.

5. Tandoi V, DiStefano TD, Bowser PA, Gossett JM, Zinder SH: Reductive dechlorination of chlorinated ethenes and halogenated ethanes by a high-rate anaerobic enrichment cultures. Environ Sci Technol 1994, 28:973-979.

6. Maymo-Gatell X, Tandoi V, Gossett JM, Zinder SH: Characterization of an $\mathrm{H}$ 2-utilizing enrichment culture that reductively dechlorinates tetrachloroethene to vinyl chloride and ethene in the absence of methanogenesis and acetogenesis. Appl Environ Microbiol 1995, 61:3928-3933

7. Ballapragada BS, Stensel HD, Puhakka JA, Ferguson JF: Effect of hydrogen on reductive dechlorination of chlorinated ethenes. Environ Sci Technol 1997, 31(6):1728-1734.

8. Russell HH, Mathews JE, Sewell GW: EPA Groundwater Issue: TCE removal from contaminated soil and ground water. US Environmental Protection Agency. 1992. EPA/540/S-92/002.

9. Dobaradaran S, Nabizadeh R, Mahvi AH, Mesdaghinia A, Naddafi K, Yunesian M, Rastkari N, Nazmara S: Survey on degradation rates of trichloroethene aqueous solution by ultrasound. Iran J Environ Health Sci Eng 2010, 7:307-312.

10. Mahvi AH, Maleki A, Rezaee R, Safari M: Reduction of humic substances in water by application of ultrasound waves and ultraviolet irradiation. Iran J Environ Health Sci Eng 2009, 6(4):233-240.

11. Mahvi AH: Application of ultrasonic technology for water and wastewater treatment. Iran J Public Health 2009, 38(2):1-17.

12. Dobaradaran S: Survey on the potential of hybrid technologies (photooxidation and photosonic) for degradation and toxicity reduction of trichloroethylene (TCE) in contaminated waters. Tehran University Of Medical Sciences: PhD dissertation (in Persian); 2011

13. Haag WR, Johnson MD, Scofield R: Direct photolysis of trichloroethene in air: Effect of cocontaminants, toxicity of products, and hydrothermal treatment of products. Environ Sci Technol 1996, 30(2):414-421.

14. Mark DJ, Haag WR, Blystone PG: Destruction of Organic Contaminants in Air Using Advanced Ultraviolet Flash Lamps; Final Report on EPA Contract CR 818209-01-0. U. S. EPA, Cincinnati OH 45268. 1992

15. Blystone PG, Johnson MD, Haag WR, Daley PF: In Advanced Ultraviolet Flash Lamps for the Destruction of Organic Contaminants in Air; Emerging Technologies in Hazardous Waste Management III. Washington, DC: American Chemical Society; 1993:380-392.

16. Prager $L$, Hartmann E: New rote for degradation of chlorinated ethylenes in exhaust gases from ground water remediation. J Photochem Photobiol A 2001, 138:177 
17. Dobaradaran S, Nabizadeh R, Mahvi AH, Noroozi A, Yunesian M, Rastkari N, Nazmara S, Zarei S: Kinetic and degradation efficiency of trichloroethylene (TCE) via photochemical process from contaminated water. Afr J Biotechnol 2012, 11:2006-2012.

18. Chu W, Choy WK: The study of lag phase and rate improvement of TCE decay in UV/surfactant systems. Chemosphere 2000, 41(8):1199-1204.

19. Sundstrom DW, Klei HE, Nalette TA, Reidy DJ, Weir BA: Destruction of halogenated aliphatics by ultraviolet catalyzed oxidation by hydrogen peroxide. Hazard Waste Hazard Mater 1986, 3:101.

20. Hirvonen A, Tuhkanen T, Kalliokoski P: Formation of chlorinated acetic acids during UV/H202-oxidation of ground water contaminated with chlorinated ethylenes. Water Sci Technol 1996, 33:67.

21. Li K, Stefan MI, Crittenden JC: UV photolysis of trichloroethylene: Product study and kinetic modeling. Environ Sci Technol 2004, 38(24):6685-6693.

22. Hirvonen A, Tuhkanen T, Kalliokoski P: Formation of chlorinated acids during UV/H2O2 -oxidation of groundwater contaminated with chlorinated ethylenes. Chemosphere 1996, 32:1091.

23. Mertens R, Von Sonntag CJ: Photolysis $(I=254 \mathrm{~nm})$ of tetrachloroethene in aqueous solutions. Photochem Photobiol A 1995, 85:1.

24. Yamada $\mathrm{H}$, Tsuno $\mathrm{H}$ : Characteristics of advanced oxidation for the decomposition of organic compounds. Journal of the Chinese Institute of Environmental engineering 2000, 10:61-68.

25. Chu W, Jia J: The Photodegradation and Modeling of a Typical NAPL, Trichloroethene, by Monochromatic UV Irradiations. Environ Sci Technol 2009, 43(5):1455-1459

26. Bajpai RK, Zappi ME: Bioremediation of Surface and Subsurface Contamination. N Y Acad Sci 1997, 829:83-96.

27. von Sonntag C: Advanced oxidation processes: mechanistic aspects. Water Sci Technol 2008, 58(5):1015-1021.

doi:10.1186/2052-336X-12-16

Cite this article as: Dobaradaran et al:: Transformation efficiency and formation of transformation products during photochemical degradation of TCE and PCE at micromolar concentrations. Iranian Journal of Environmental Health Science \& Engineering 2014 12:16.

\section{Submit your next manuscript to BioMed Central and take full advantage of:}

- Convenient online submission

- Thorough peer review

- No space constraints or color figure charges

- Immediate publication on acceptance

- Inclusion in PubMed, CAS, Scopus and Google Scholar

- Research which is freely available for redistribution 